\title{
Zimné športy vo vyučovaní telesnej a športovej výchovy na stredných školách
}

\section{The winter sports in physical education teaching at the secondary schools}

\author{
Boris Bet’ák
}

Filozofická fakulta Univerzity Mateja Bela v Banskej Bystrici, Slovensko

\begin{abstract}
Abstrakt:
Autor v prispevku prezentuje výsledky výskumu zameraného na zistenie, ktoré zimné športy sa využivajú $v$ rámci vyučovania telesnej a športovej výchovy na stredných školách v okresoch Martin a Stará Lubovňa a aký je stav ich vyučovania. Použitou výskumnou metódou bol dotazník vlastnej konštrukcie, ktorý pozostával z 21 otázok. Výskumnú vzorku tvorilo spolu 435 žiakov (247 chlapcov a 188 dievčat) 10-tich stredných škôl v okrese Martin a 5-tich stredných škôl v okrese Stará Lubovňa, z ktorých sa kurzu pohybových aktivít v prírode so zameraním na zimné športy zúčastnilo 228 žiakov (132 chlapcov a 96 dievčat). Na základe výsledkov autor konštatuje, že na všetkých stredných školách v okrese Stará L’ubovňa a na 8 z 10 stredných školách v okrese Martin sa realizuje kurz pohybových aktivít v prírode so zameraním na zimné športy, v rámci ktorého dané školy realizujú bud’ len lyžiarsky kurz, alebo spojený lyžiarsky kurz s kurzom snowboardingu.
\end{abstract}

\begin{abstract}
:
In this contribution, the author has presented the research results targeted to the finding, what kind of winter sports have been practised in the framework of Physical education teaching at the secondary schools in Martin and Stara Lubovna district. Moreover, he has also presented what is the condition of their teaching. The research method, which was used, was a self-made questionnaire that consisted from 21 questions. A research sample involved 435 students altogether (247 boys and 188 girls) from ten secondary schools in Martin district and five secondary schools in Stara Lubovna district. In addition, 228 students (132 boys and 96 girls) took part in the instruction of movement activities in the natural countryside targeted to the winter sports. On the basis of the results, the author has claimed that the movement activities in the natural countryside targeted to winter sports have been carried out at all secondary schools in Stara Lubovna district, and 8 from 10 secondary schools in Martin district. Moreover, the above mentioned secondary schools have either carried out the ski instruction on its own or the ski instruction with a snowboarding one altogether.
\end{abstract}

Kl'účové slová: žiaci stredných škôl, zimné športy, telesná a športová výchova

Key words: students of secondary schools, winter sports, physical education

\section{ÚVOD}

Telesná a športová výchova je hlavným prostriedkom všestranného telesného rozvoja žiakov. Realizácia úloh vyplývajúcich z ciel'ov telesnej výchovy je závislá od podmienok, obsahu, od úrovne žiakov a aj od úrovne učitel'a, jeho skúseností, veku, flexibility, od úrovne jeho vedomostí, a pod. (Adamčák \& Nemec, 2010).

Vyučovanie zimných športov sa realizuje $\mathrm{v}$ rámci kurzu pohybových aktivít v prírode so zameraním na zimné športy (lyžiarsky kurz, snowboardový kurz). Uskutočňuje sa formou kurzovej výučby, ktorá má povinný obsah a riadi sa samostatnými smernicami (Štátny vzdelávací program, 2009).

Paugschová (2004) uvádza, že lyžovanie má v rámci telesnej a športovej výchovy dlhoročnú tradíciu. Práve lyžovanie považuje Michal (2001) za jeden z najzdravších športov nielen vd’aka prostrediu, v ktorom sa lyžiar pohybuje, ale aj kvôli všestrannosti pohybu, ktorý je nútený na lyžiach vykonávat'. 
Kurz pohybových aktivít v prírode so zameraním na zimné športy je súčast'ou vyučovania telesnej a športovej výchovy na školách poskytujúcich základné vzdelanie a na školách poskytujúcich stredné a vyššie vzdelanie vrátane stredných odborných učilíšt' a odborných učilišst' a má samostatnú časovú dotáciu. Na stredných školách sa ho zúčastňujú žiaci a žiačky 1. ročníka, prípadne žiaci a žiačky ostatných ročníkov týchto škôl, ktoré majú lyžiarske (snowboardové) kurzy stanovené vo svojich školských vzdelávacích programoch inak (Modrák, Pavlov, Roučková, \& Povrazník, 2008).

\section{CIEL}

Ciel'om práce bolo analyzovat' organizáciu kurzu pohybových aktivít v prírode so zameraním na zimné športy na stredných školách v okresoch Martin a Stará L'ubovňa.

\section{METODIKA}

Výskumnú vzorku tvorilo 233 žiakov stredných škôl v okrese Martin (126 chlapcov a 107 dievčat) a 202 žiakov stredných škôl v okrese Stará Luubovňa (121 chlapcov a 81 dievčat), čo spolu predstavuje 435 žiakov (247 chlapcov a 188 dievčat). Výskum sme realizovali v marci a apríli 2013.

Použili sme opytovaciu metódu, konkrétne dotazník. Dotazník bol anonymný, obsahoval 21 otázok a bol určený pre žiakov stredných škôl v okresoch Martin a Stará L’ubovňa. Jeho zameranie bolo na zistenie názorov a záujmov žiakov na zimné športy, vyučovanie a realizáciu kurzu pohybových aktivít v prírode so zameraním na zimné športy. V príspevku uvádzame odpovede len na vybrané otázky.

Pri spracovaní získaného faktografického materiálu sme použili matematicko-štatistické metódy (percentá, Chí-kvadrát), grafické metódy (obrázky) a kvalitatívne metódy (komparáciu, analýzu, syntézu, indukciu, dedukciu). Získané údaje sme vyhodnocovali z pohl’adu intersexuálnych vzt’ahov.

\section{VÝSLEDKY A DISKUSIA}

Na základe výsledkov konštatujeme, že takmer na všetkých stredných školách v okresoch Martin a Stará Lubbovňa sa kurz pohybových aktivít v prírode so zameraním na zimné športy realizuje bud' pravidelne (uviedlo $61,13 \%$ chlapcov a 72,87 \% dievčat), alebo podl'a záujmu žiakov (uviedlo 30,36 \% chlapcov a 20,21 \% dievčat). Kurz pohybových aktivít $\mathrm{v}$ prírode so zameraním na zimné športy sa nerealizuje len na 2 z 10 stredných škôl v okrese Martin, čo uviedlo $8,50 \%$ chlapcov a 6,91 \% dievčat (obrázok 1). To, že sa zimné kurzy organizujú takmer na všetkých stredných školách, na ktorých sme robili výskum, hodnotíme vysoko pozitívne, pretože na týchto kurzoch sa upevňujú sociálne vzt'ahy medzi žiakmi aj medzi žiakmi a učitel'om a navyše pobyt a pohyb v prírode pozitívne pôsobí na organizmus človeka a jeho zdravie. Pri tejto otázke sme zaznamenali štatisticky významné rozdiely v odpovediach chlapcov a dievčat na hladine významnosti $\mathrm{p}<0,05$.

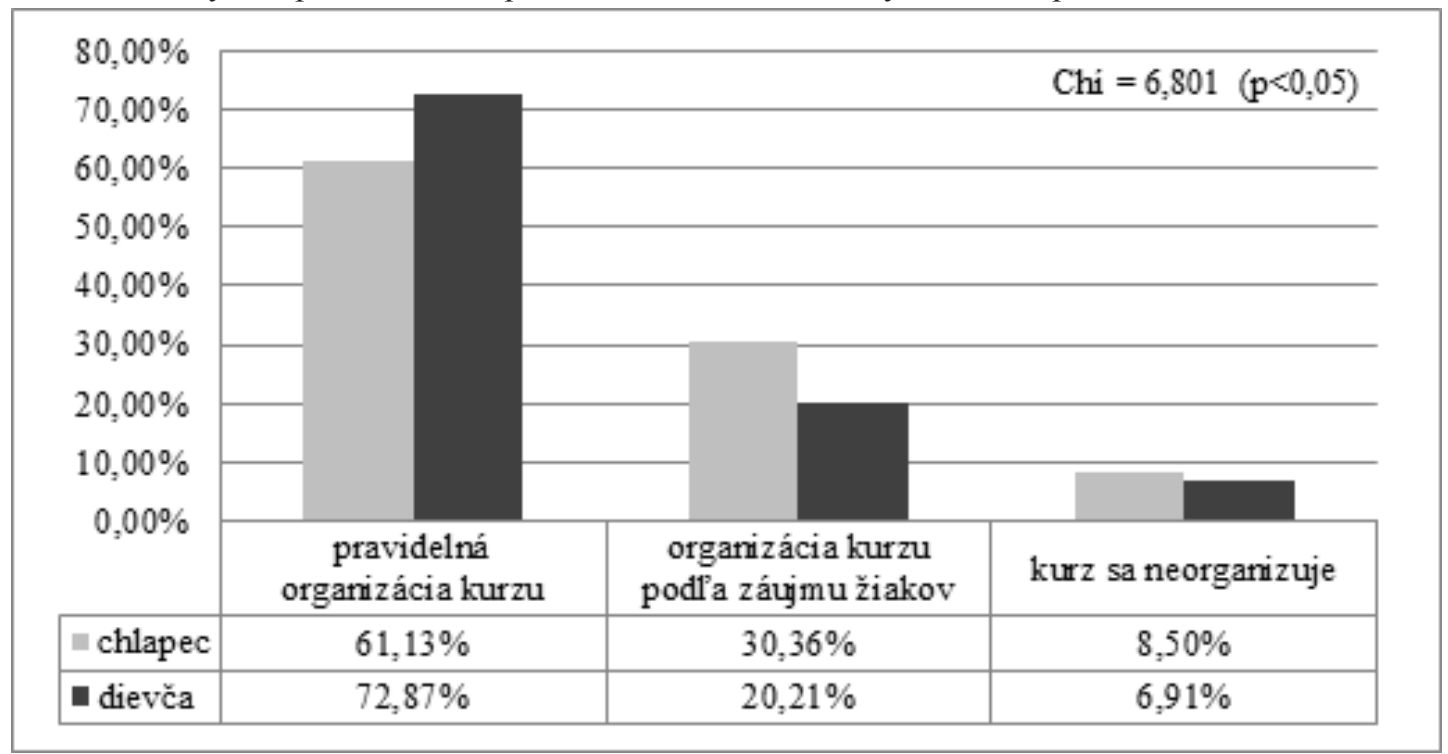

Obr. 1: Spôsob organizovania kurzu pohybových aktivít v prírode so zameraním na zimné športy 
Zist'ovali sme aj, kol'ko žiakov stredných škôl v okresoch Martin a Stará L'ubovňa, sa zúčastnilo kurzu pohybových aktivít $\mathrm{v}$ prírode so zameraním na zimné športy. Výsledky prezentujeme na obrázku 2. Kurzu pohybových aktivít $\mathrm{v}$ prírode so zameraním na zimné športy sa zúčastnilo 53,44 \% chlapcov a 51,06 \% dievčat, čo predstavuje 228 žiakov (132 chlapcov a 96 dievčat). Na danom kurze sa nezúčastnilo až 46,56 \% chlapcov a 48,94 \% dievčat, čo predstavuje 207 žiakov. Výsledky nás prekvapili, nakol'ko sme predpokladali vyššiu percentuálnu účast' žiakov na tomto kurze, pretože zimné športy sú vel’mi obl'úbené (Nevolná, 2013) a prírodné podmienky na realizáciu zimných športov sú v týchto regiónoch vel'mi priaznivé.

Podobné výsledky zistili Veisová (2006), ktorá uvádza viac ako 54 \% účast' žiakov stredných škôl na takomto kurze a Michal (2012a) konštatuje viac ako 59 \% účast’ žiakov stredných škôl. Na základných školách zistili Paugschová \& Kubašč́k (2002) dokonca až cez 85 \% účast’ žiakov na tomto kurze.

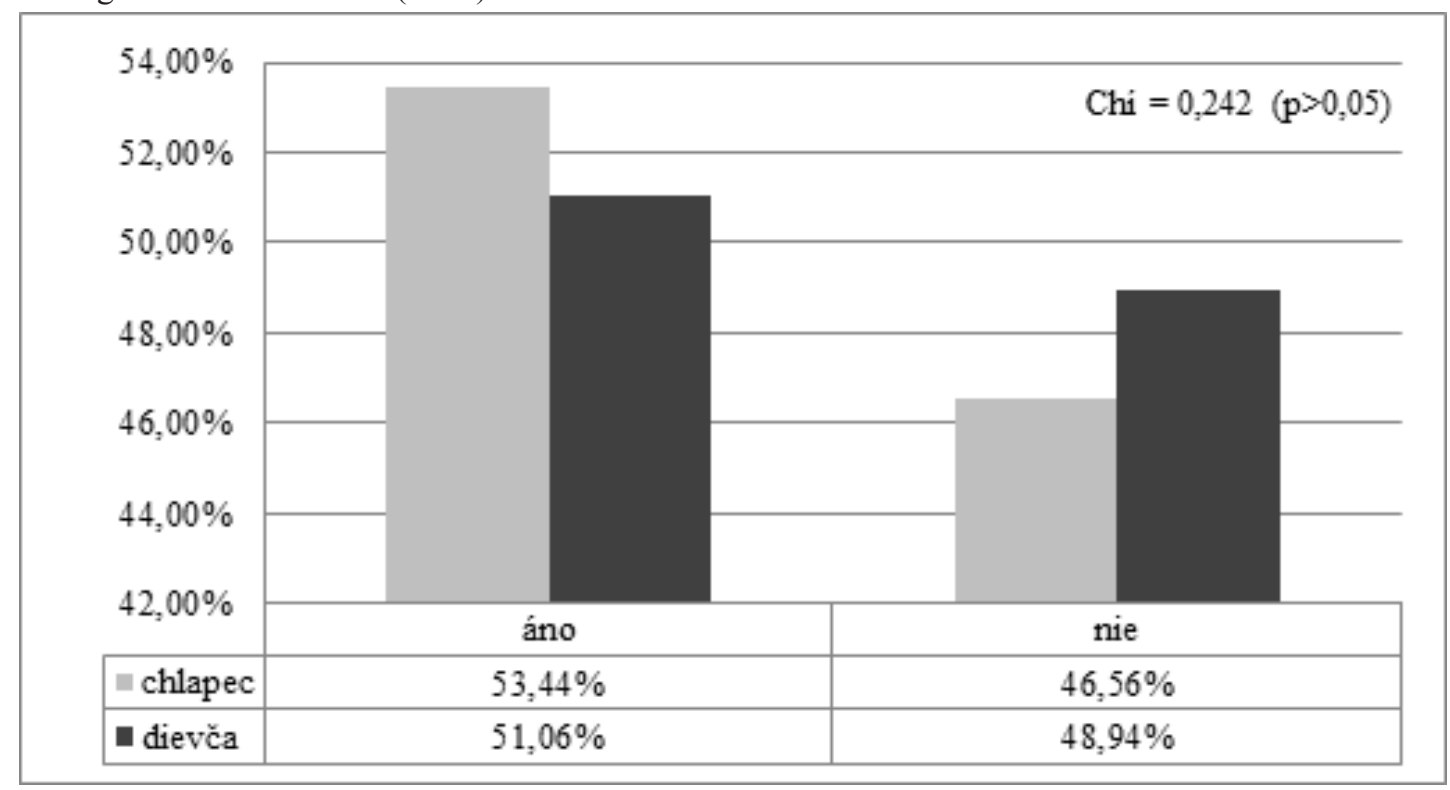

Obr. 2: Účast’žiakov na kurze pohybových aktivit v prírode so zameraním na zimné športy

Poznat' vzt'ah žiakov k pohybovej činnosti a poznat' názory a dôvody prečo danú činnost' vykonávajú resp. nevykonávajú je nevyhnutné pokial' chceme vhodne motivovat' žiakov k aktívnej účasti na vyučovaní a získat' ho pre pravidelnú pohybovú činnost'.

Ked’že neúčast’ žiakov stredných škôl v okresoch Martin a Stará L'ubovňa na kurze pohybových aktivít v prírode so zameraním na zimné športy bola takmer $50 \%$, zaujímalo nás, aké sú najčastejšie uvádzané dôvody tejto neúčasti. Odpovede žiakov boli rôzne, pričom žiaci mali na výber 6 možností. Jedna z možností, možnost' „iné“, dávala priestor žiakom uviest' iný dôvod ako sme v dotazníku ponúkali.

Ako môžeme vidiet' na obrázku 3, možnost' „iné“ si vybralo až 32,17 \% chlapcov a 23,91 \% dievčat. Najčastejšie uvádzanými dôvodmi neúčasti na kurze pohybových aktivít v prírode so zameraním na zimné športy boli: nízky záujem žiakov o tento kurz a nechut’ každodenne dochádzat’ do lyžiarskeho strediska. 


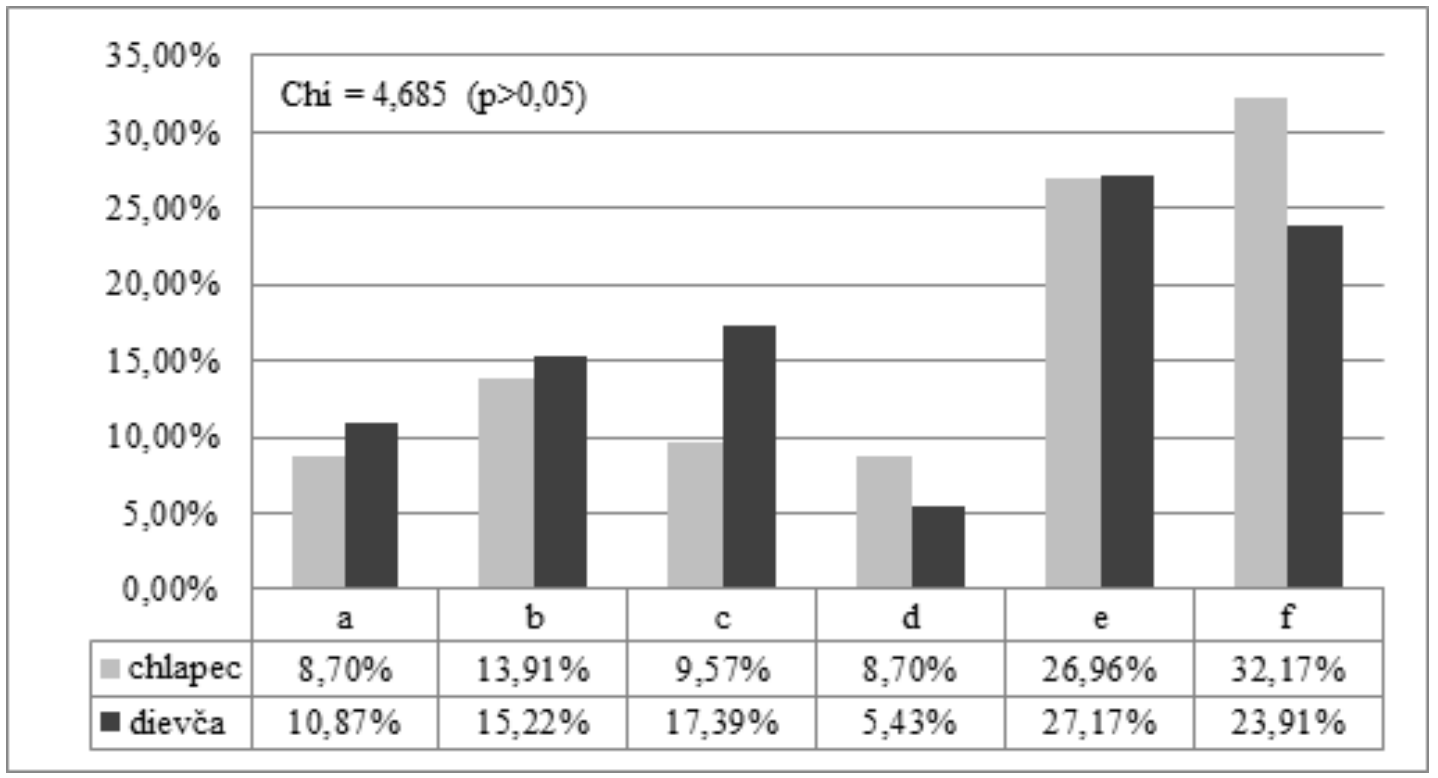

Obr. 3: Dôvody neúčasti žiakov na kurze pohybových aktivít v prírode so zameraním na zimné športy Legenda:

a-kurz sa realizuje vo vyššom ročníku

$b-k u r z$ bol príliš drahý

$c$ - mám negativny vztah $k$ zimným športom

e-zdravotné dôvody

$d$-je to strata času, radšej budem v škole

$f$-iné

Ako druhý najčastejší dôvod neúčasti na kurze pohybových aktivít v prírode so zameraním na zimné športy uviedlo až 26,96 \% chlapcov a 27,17 \% dievčat zdravotné problémy. Práve zdravotné problémy žiakov sú najčastejším dôvodom neúčasti žiakov na tomto kurze vo výskumoch Michala (2006, 2007). Michal (2006) a Paugschová \& Kubaščík (2002) okrem zdravotných dôvodov uvádzajú ako častý dôvod aj nevlastnenie lyžiarskeho výstroja. Ako d'alšie dôvody neúčasti na tomto kurze uviedli žiaci negatívny vzt’ah k zimným športom (9,57 \% chlapcov a 17,39 \% dievčat), a že kurz bol príliš drahý (13,91 \% chlapcov a 15,22 \% dievčat). Finančnú náročnost' kurzu uvádza ako hlavný dôvod neúčasti žiakov Michal (2012a).

Z celkového počtu 435 žiakov stredných škôl v okresoch Martin a Stará Lubovňa sa kurzu pohybových aktivít v prírode so zameraním na zimné športy zúčastnilo 228 žiakov. Zaujímalo nás, aké boli dôvody týchto žiakov pre účast' na tomto kurze. Obrázok 4 prezentuje, že najčastejším dôvodom účasti na tomto kurze je pozitívny vzt'ah žiakov k zimným športom. Túto možnost' zvolilo 40,15 \% chlapcov a 30,21 \% dievčat. Zistený fakt považujeme za vel'mi pozitívny, nakol'ko žiakov, ktorí prejavujú záujem o vyučovanie je jednoduchšie motivovat' a pracuje sa s nimi omnoho lepšie. 


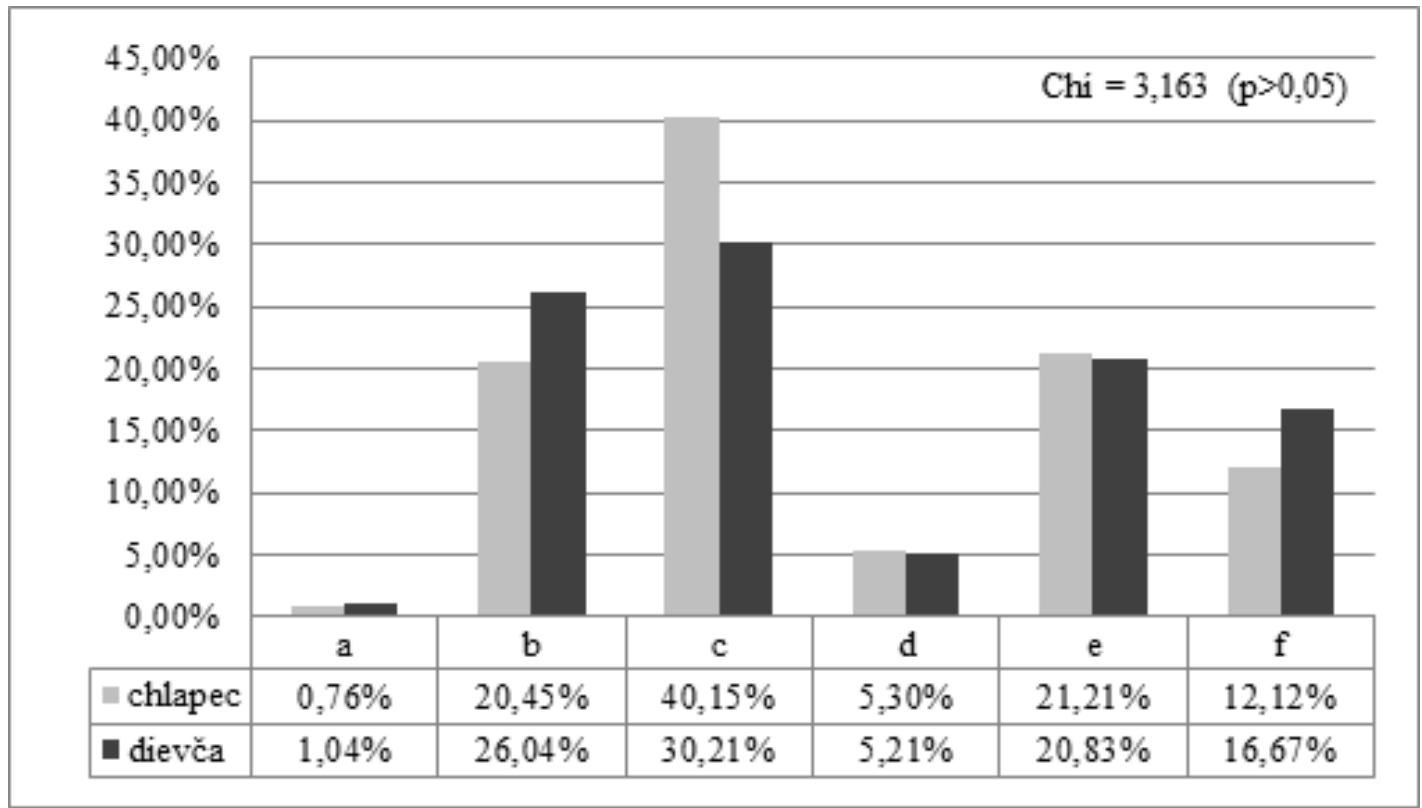

Obr. 4: Dôvody účasti žiakov na kurze pohybových aktivít v prírode so zameraním na zimné športy Legenda:

a-kurz bol povinný

$c$ - mám pozitívny vzt’ah $k$ zimným športom

$b-$ zlepšenie lyžiarskych zručností

e-nemusel/a som ist' do školy

$d$-rodičia ma prinútili

f-na kurzoch je zábava

Na základe výsledkov uvedených na obrázku 4 konštatujeme, že druhým najčastejšie uvádzaným dôvodom zo strany dievčat bol záujem o zlepšenie lyžiarskych zručností, o ktorý prejavilo záujem 26,04 \% dievčat. Záujem o zlepšenie lyžiarskych zručností uviedlo aj 20,45 \% chlapcov. Ako hlavný dôvod účasti žiakov na kurze pohybových aktivít $\mathrm{v}$ prírode so zameraním na zimné športy uviedlo záujem o zlepšenie lyžiarskych zručností aj 39,30 \% žiakov vo výskume Michala (2012a). Zaujímavé zistenia sme zaznamenali pri odpovediach „nemusel/a som íst' do školy“ (uviedlo cez 20 \% v oboch pohlaviach) a „na kurzoch je zábava“ (uviedlo 12,12 $\%$ chlapcov a $16,67 \%$ dievčat).

Podl'a Štátneho vzdelávacieho programu sa môže lyžovanie (snowboarding) realizovat' dvojakou formou, bud' ako lyžiarsky výcvik s dennou dochádzkou alebo formou lyžiarskeho zájazdu. Na obrázku 5 prezentujeme akou formou bol organizovaný kurz pohybových aktivít v prírode so zameraním na zimné športy, ktorého sa žiaci v okresoch Martin a Stará L’ubovňa zúčastnili.

Z výsledkov jasne vyplýva, že väčšina žiakov sa daného kurzu zúčastnila formou lyžiarskeho zájazdu. Túto formu organizácie kurzu uviedlo 75,76 \% chlapcov a 81,25 \% dievčat. Kurzu pohybových aktivít v prírode so zameraním na zimné športy realizovaného dennou dochádzkou sa zúčastnilo $24,24 \%$ chlapcov a $18,75 \%$ dievčat. Len na dvoch školách v okrese Stará Lubovňa a jednej strednej škole v okrese Martin, sú lyžiarske (snowboardové) kurzy uskutočňované formou dennej dochádzky.

Až $100 \%$ organizáciu zimných kurzov zájazdovou formou zistil na 20 základných a 21 stredných školách v Olomouci a okolí Mázal (2011).

Na základných školách Paugschová \& Kubaščík (2002) a Michal (2009) poukazujú na prevahu organizácie kurzu pohybových aktivít $\mathrm{v}$ prírode so zameraním na zimné športy, dochádzkovou formou. K podobným výsledkom dospel aj Michal (2006), ktorý preferovanie realizácie kurzu pohybových aktivít v prírode so zameraním na zimné športy dochádzkovou formou zistil u 88 \% základných škôl v okrese Martin. Za hlavný dôvod preferovania dochádzkovej formy realizácie kurzov pred realizovaním kurzov zájazdom považuje Michal (2006), vyššiu náročnost’ na organizáciu kurzu zájazdom. 


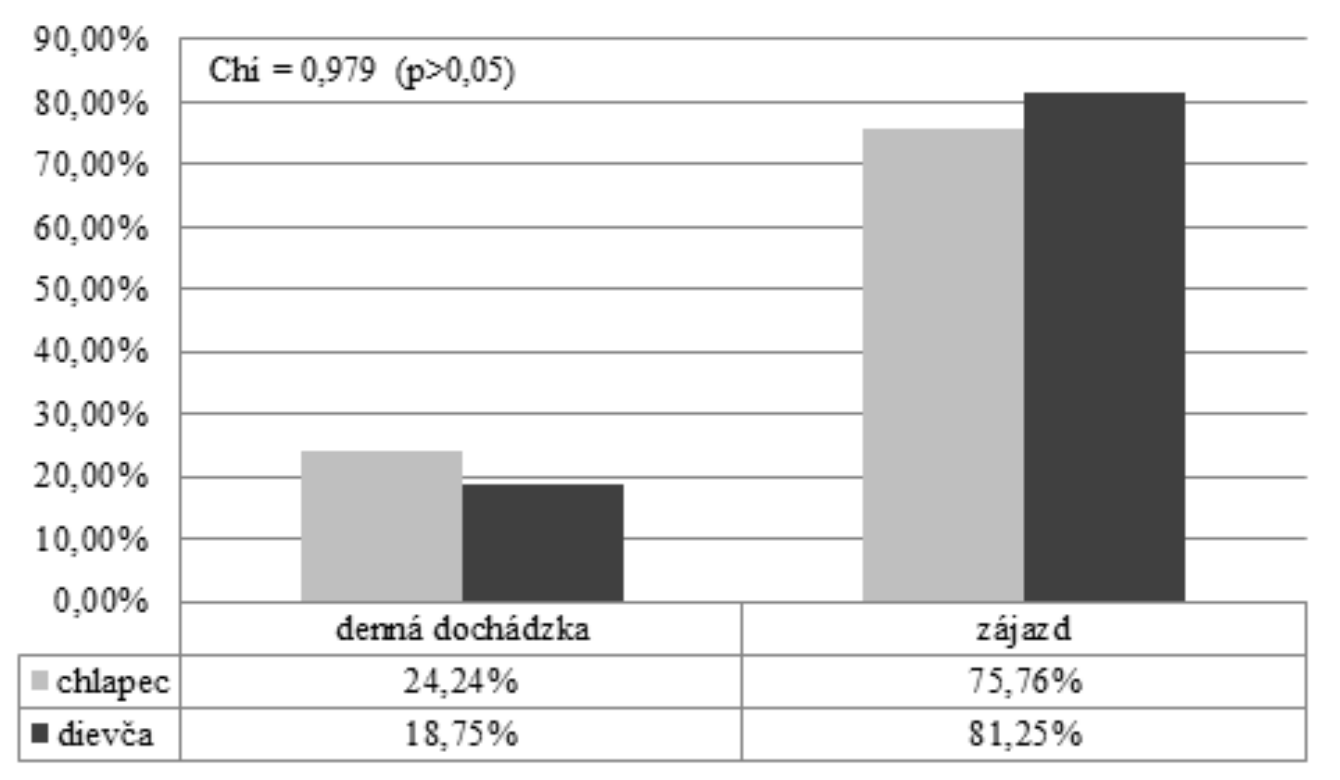

Obr. 5: Forma organizácie kurzu pohybových aktivit v prírode so zameraním na zimné športy

V otázke, ktoré zimné športy sa realizovali na kurze pohybových aktivít v prírode so zameraním na zimné športy, na ktorom ste sa zúčastnili, uviedli žiaci stredných škôl v okresoch Martin a Stará L'ubovňa len dve odpovede. Až 63,64 \% chlapcov a 53,13 \% dievčat uviedlo, že na kurze, ktorého sa zúčastnili, sa vyučovalo aj zjazdové lyžovanie, aj snowboarding. Ostatní žiaci uviedli, že počas kurzu pohybových aktivít so zameraním na zimné športy, ktorého sa zúčastnili, sa realizovalo len zjazdové lyžovanie. Za prekvapivé považujeme, že ani jeden žiak neuviedol, že by sa v rámci kurzu pohybových aktivít v prírode so zameraním na zimné športy vyučoval výlučne snowboarding.

Je však potešujúce, že nadpolovičná väčšina žiakov sa zúčastnila kurzu pohybových aktivít v prírode so zameraním na zimné športy, ktorý dával možnost' zvolit' si snowboarding ako plnohodnotnú alternatívu popri zjazdovom lyžovaní, pretože zo snowboardingu sa stal masovo rozšírený a profesionálne uznávaný šport (Binter, Binter and Černík, 2012).

Z výsledkov vyplýva, že školy implementovali snowboarding do svojich školských vzdelávacích programov, čo umožnila reforma školstva v roku 2008. Daný stav hodnotíme pozitívne, pretože výskumy Modráka \& Nemčíka (2006), Krála (2007), Michala (2010, 2012b) a Bet'áka (2012) poukazujú na vysoký záujem žiakov o snowboarding.

Vo výskume sme tiež zist'ovali, konkrétne ktorých zimných športov sa žiaci stredných škôl v okresoch Martin a Stará L'ubovňa aktívne zúčastnili počas realizácie kurzu pohybových aktivít v prírode so zameraním na zimné športy (lyžiarsky kurz, snowboardový kurz). Žiaci mohli zvolit’ jednu z možností: zjazdové lyžovanie, snowboarding a oba športy. Výsledky prezentujeme na obrázku 6. 


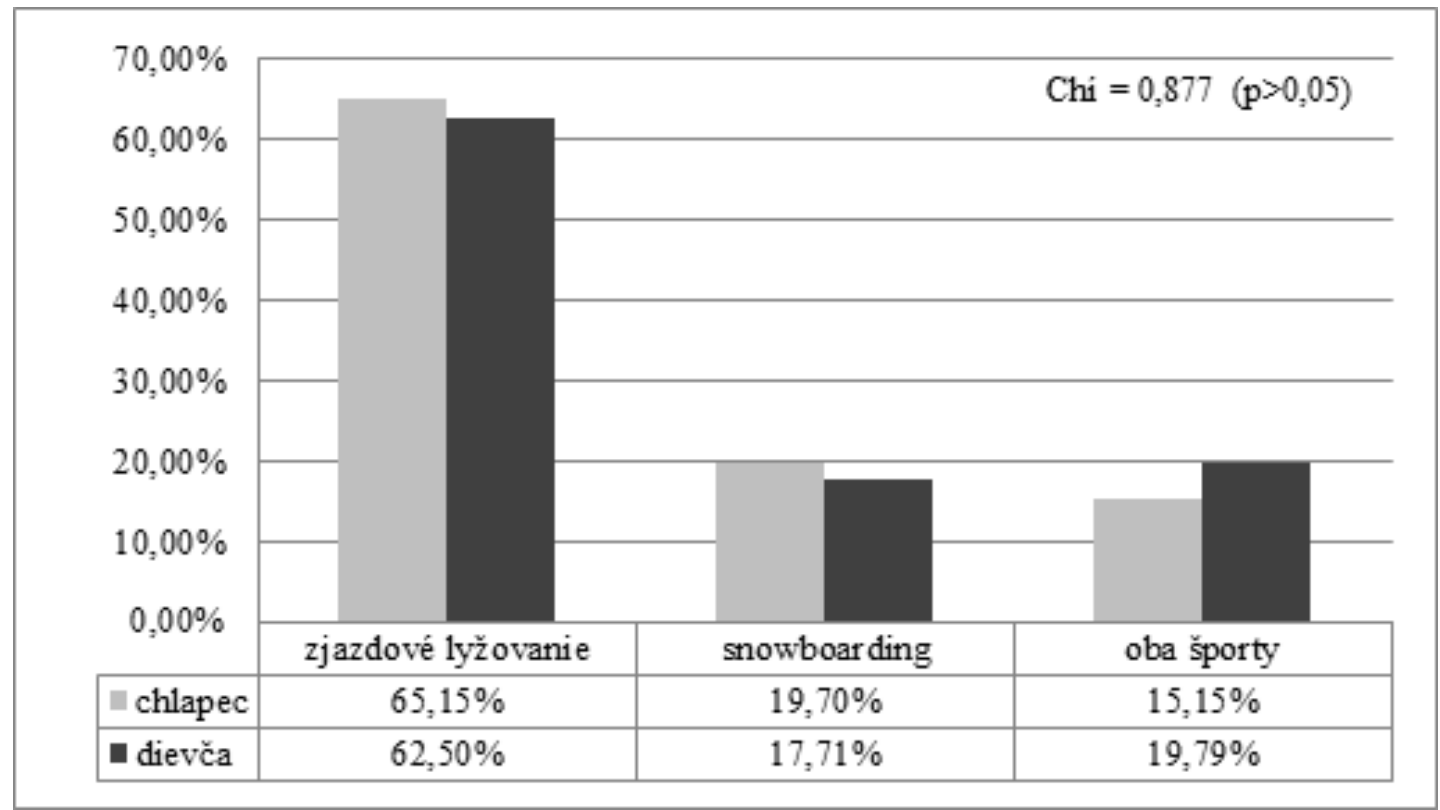

Obr. 6: Zimné športy, ktorých sa žiaci zúčastnili počas kurzu pohybových aktivít v prírode so zameraním na zimné športy

Na kurze pohybových aktivít v prírode so zameraním na zimné športy sa zúčastnilo zjazdového lyžovania až $65,15 \%$ chlapcov a $62,50 \%$ dievčat. Takýto výrazný výsledok v prospech zjazdového lyžovania sme však neočakávali. Súvisiet' to môže s faktom, ktorý uvádza Michal (2007), že zjazdové lyžovanie má vel'kú tradíciu a stále sa teší vel'kej popularite.

Sme trochu prekvapení, že snowboardingu sa zúčastnilo menej žiakov, ako sme predpokladali, nakol'ko výskumy Krála (2007), Michala (2010, 2012b) a Bet’áka (2012) poukazujú na vysokú atraktivitu tohto športu a rastúci záujem o jeho vykonávanie. Samotného vyučovania snowboardingu sa zúčastnilo $19,70 \%$ chlapcov a $17,71 \%$ dievčat a vyučovania oboch zimných športov sa zúčastnilo $15,15 \%$ chlapcov a $19,79 \%$ dievčat.

Ked’že až 63,64 \% chlapcov a 53,13 \% dievčat uviedlo, že na kurze, ktorého sa zúčastnili, sa vyučovalo aj zjazdové lyžovanie, aj snowboarding, predpokladali sme vyššie percento žiakov, ktorí sa vyučovania snowboardingu reálne zúčastnili. Tieto výsledky však môžu súvisiet’ aj s finančnou náročnost'ou tohto športu, prípadne s rozhodnutím žiakov venovat' sa na kurze len jednému zimnému športu, pričom zrejme uprednostnili zjazdové lyžovanie.

Podobný výskum realizoval aj Zemanovič (2011), ktorý uvádza, že 85 \% žiakov stredných škôl uprednostnilo na kurze pohybových aktivít v prírode so zameraním na zimné športy zjazdové lyžovanie pred snowboardingom.

\section{ZÁVER}

Výsledky zverejnené v našom príspevku prezentujú analýzu organizácie kurzu pohybových aktivít v prírode so zameraním na zimné športy na stredných školách v okresoch Martin a Stará Lubovňa.

Pomocou dotazníka sme zistili, že kurz pohybových aktivít v prírode so zameraním na zimné športy sa realizuje na všetkých stredných školách v okrese Stará L’ubovňa a na ôsmich stredných školách v okrese Martin. Stredné školy v okresoch Martin a Stará Lubovňa realizujú kurz pravidelne alebo podl'a záujmu žiakov. Pri spôsobe organizácie kurzu pohybových aktivít v prírode so zameraním na zimné športy sme zaznamenali štatisticky významné rozdiely v odpovediach chlapcov a dievčat na hladine významnosti $p<0,05$ (chí=6,801). Školy realizujú vyučovanie zimných športov bud' len ako lyžiarsky kurz, alebo spojený lyžiarsky kurz s kurzom snowboardingu. Kurzu pohybových aktivít v prírode so zameraním na zimné športy sa aktívne zúčastnilo 53,44 $\%$ chlapcov a $51,06 \%$ dievčat.

Najčastejšími dôvodmi účasti na tomto kurze boli pozitívny vzt’ah žiakov k zimným športom (40,15\% chlapcov a 30,21 \% dievčat) a záujem žiakov o zlepšenie lyžiarskych zručností (20,45 \% chlapcov a 26,04 \% dievčat). Prevažná väčšina žiakov sa zúčastnila kurzu realizovaného formou zájazdu. Až 63,64 \% chlapcov 
a 53,13 \% dievčat uviedlo, že na kurze, ktorého sa zúčastnili, sa vyučovalo aj zjazdové lyžovanie, aj snowboarding, pričom väčšina žiakov sa rozhodla len pre vyučovanie zjazdového lyžovania.

Najčastejšie uvádzanými dôvodmi neúčasti na kurze pohybových aktivít v prírode so zameraním na zimné športy boli: nízky záujem žiakov o tento kurz, nechut' každodenne dochádzat' do lyžiarskeho strediska či zdravotné problémy a finančná náročnost’ kurzu. Pri zvyšných otázkach sme nezaznamenali štatisticky významné rozdiely v odpovediach chlapcov a dievčat.

Na základe zistených výsledkov odporúčame v rámci zvýšenia záujmu žiakov o vyučovanie zimných športov organizovat' zimný kurz zájazdovou formou, zaradit' snowboarding ako pevnú súčast' realizácie vyučovania zimných športov a zabezpečit’ finančnú alebo materiálnu podporu pre organizovanie kurzu.

\section{LITERATÚRA}

Adamčák, Š., \& Nemec, M. (2010). Pohybové hry a školská telesná a športová výchova. Banská Bystrica, Slovakia: Fakulta humanitných vied UMB, Univerzita Mateja Bela v Banskej Bystrici.

Beták, B. (2012). The attitude of students at secondary schools towards snowboarding and the way of teaching it. Acta Universitatis Matthiae Belii physical education and sport, 4 (2), 16-26. Retrieved from http://www.fhv. umb.sk/katedry/katedra-telesnej-vychovy-a-sportu/veda-a-vyskum/acta-universitatis-matthiae-belii-physicaleducation-and-sport-vedecky-casopis.html.

Binter, L., Binter, A., \& Černík, M. (2012). Snowboarding (4th ed.). Praha, Czechia: Grada.

Král, L. (2007). Súčasný stav a zmeny vo vyučovaní zjazdového lyžovania na základných školách v Banskej Bystrici a v Brezne. In K. Krnová (Ed.), Mladá veda 2007: zborník vedeckých štúdii doktorandov FHV UMB v Banskej Bystrici. (pp. 360-371). Banská Bystrica, Slovakia: Fakulta humanitných vied UMB, Univerzita Mateja Bela v Banskej Bystrici.

Mazal, Z. (2011). Výuka snowboardingu na základnich a středních školách v Olomouci a okolí (master's thesis, Masaryk University, Brno, Czechia). Retrieved from http://is.muni.cz/th/364579/fsps_m/?lang=en;id=170751. Michal, J. (2001). Teória a didaktika lyžovania. Banská Bystrica, Slovakia: Pedagogická fakulta, Univerzita Mateja Bela v Banskej Bystrici.

Michal, J. (2006). Analýza stavu lyžovania na základných školách. In J. Michal \& P. Bartík (Eds.), Súčasnost’a perspektivy telovýchovného procesu na školách: recenzovaný zborník vedecko-výskumných prác - Vedy o športe. (pp.186-196). Banská Bystrica, Slovakia: Pedagogická fakulta, Univerzita Mateja Bela v Banskej Bystrici.

Michal, J. (2007). Lyžovanie na druhom stupni základnej školy. Banská Bystrica, Slovakia: Pedagogická fakulta, Univerzita Mateja Bela v Banskej Bystrici.

Michal, J. (2009). Názory žiakov na realizáciu snowboardového výcviku na školách. Studia sportiva, 3 (2), $99-106$.

Michal, J. (2010). Snowboarding ako súčast’ telesnej výchovy. In K. Baisová \& M. Kružliak (Eds.), Telesná výchova - prostriedok vytvárania vzt’ahu mladej generácie k pohybu a športu: 1. ročník vedeckej konferencie. (pp. 89-103). Zvolen, Slovakia: Technická univerzita.

Michal, J. (2012a). Vyučovanie lyžovania v intencií štátneho vzdelávacieho programu na stredných školách. In K. Baisová \& M. Kružliak (Eds.), Telesná výchova a šport - prostriedok vytvárania vzt’ahu mladej generácie k pohybu a športu: 3. ročník vedeckej konferencie s medzinárodnou účastou. (pp. 166-177). Zvolen, Slovakia: Technická Univerzita.

Michal, J. (2012b). Snowboarding a štátny vzdelávací program na školách. In K. Baisová \& M. Kružliak (Eds.), Telesná výchova a šport - prostriedok vytvárania vzt’ahu mladej generácie k pohybu a športu: 3. ročník vedeckej konferencie. (pp. 178-186), Zvolen, Slovakia: Technická Univerzita.

Modrák, M., \& Nemčík, R. (2006). O potrebe zaradenia nácviku aj snowboardingu do učebných osnov pre žiakov ZŠ a SŠ. In J. Jakubíková \& M. Modrák (Eds.), Zborník prác z 11. vedecko-pedagogickej konferencie Zdravá škola. (pp. 98-100). Prešov, Slovakia: Metodicko-pedagogické centrum.

Modrák, M., Pavlov, I., Roučková, M., \& Povrazník, K. (2008). Návrh realizácie prípravy lektorov zjazdového lyžovania. In V. Bebčáková \& M. Modrák (Eds.), Telesná výchova a šport, zdravie a pohyb: zborník referátov z 2. ročníka vedecko-pedagogickej konferencie učitel’ov telesnej výchovy. (pp. 169-175). Prešov, Slovakia: Prešovská univerzita, Metodicko-pedagogické centrum.

Nevolná, T. (2013). Záujmovo rekreačná telesná výchova ako účinný prostriedok k zdravému životnému štýlu. In M. Zvonař et al. (Eds.), Spolupráce v kinantropologii I. (pp. 358-371). Brno, Czechia: Masarykova univerzita Brno. 
Paugschová, B., \& Kubaščík, R. (2002). Monitorovanie stavu lyžovania na základných školách Stredoslovenského regiónu. Banská Bystrica, Slovakia: Fakulta humanitných vied UMB, Univerzita Mateja Bela v Banskej Bystrici. Paugschová, B. (2004). Predhovor. In B. Paugschová et. al. (Eds.), Lyžovanie: Učebné texty pre študentov telesnej výchovy. (pp. 5). Banská Bystrica, Slovakia: Fakulta humanitných vied, Univerzita Mateja Bela v Banskej Bystrici.

Štátny vzdelávací program, Telesná a športová výchovy, Príloha ISCED 3. (2009). Retrieved from<http://www. statpedu.sk/files/documents/svp/gymnazia/vzdelavacie_oblasti/telesna_vychova_isced3.pdf>.

Veisová, M. (2006). Monitorovanie záujmu o lyžovanie a snowbording u absolventov SŠ - záujemcov o štúdium telesnej výchovy na KTVŠ PF UKF v Nitre. In J. Šimonek (Ed.), Sport and globalization. (pp. 280-284). Nitra, Slovakia: Univerzita Konštantína Filozofa.

Zemanovič, M. (2011). Vyučovanie zjazdového lyžovania na stredných školách (Unpublished bachelor thesis). Matej Bel University, Banská Bystrica, Slovakia. 